\title{
Citação:
}

Cacciatori, C, Tordoni, E, Petruzzellis, F, et al. Drivers of distance-decay in bryophyte assemblages at multiple spatial scales: Dispersal limitations or environmental control?. J Veg Sci. 2020; 31: 293- 306. https://doi.org/10.1111/jvs.12790

DOI: https://doi.org/10.1111/ivs.12790 
Article type: Research article

Co-ordinating Editor: Rune Halvorsen

\section{Drivers of distance-decay in bryophyte assemblages at multiple spatial scales: dispersal limitations or environmental control?}

Running title: Patterns of distance decay in bryophytes

Cecilia Cacciatori ${ }^{1,2^{*}}$, Enrico Tordoni ${ }^{3}$, Francesco Petruzzellis ${ }^{3}$, Cecilia Sérgio $^{1}$, César Garcial, Alessandro Chiarucci ${ }^{2}$, Giovanni Bacaro ${ }^{3}$

${ }^{1}$ Universidade de Lisboa. Museu Nacional de História Natural e da Ciência/CE3C. Rua da Escola Politécnica, 56/58. 1250-102 Lisboa, Portugal.

${ }^{2}$ BIGEA, Department of Biological, Geological and Environmental Sciences, Alma Mater Studiorum -University of Bologna, Via Irnerio 42, 40126 Bologna, Italy

${ }^{3}$ Department of Life Sciences, University of Trieste, Via L.Giorgieri 10, 34127 Trieste, Italy

*Corresponding author: cecilia.cacciatori@unicam.it

Funding Information: This study was funded by a grant from the University of Camerino for the realization of the $\mathrm{PhD}$ project of the first author and supported by Portuguese National Funds, through FCT- Fundação para a Ciência e a Tecnologia, within the project UID/BIA/00329/2013.

\section{Abstract}

Questions: Despite the increasing scientific interest in distance decay of compositional similarity in ecology, the scale-dependence of geographical vs environmental control on distance decay of biological communities has not been properly addressed so far. The present work highlights the relative importance of niche-based processes $v s$ dispersal limitations on distance decay patterns of epilithic bryophyte assemblages at different spatial scales.

Location: Serra de Sintra, central Portugal.

Methods: We adopted a nested sampling design with 32 selected sampling sites in each of which two clusters, each with five rocks, were surveyed. Each cluster was characterized by a set of 15 macro-scale variables, which were divided into environmental and anthropogenic. For each rock eight micro-scale variables were recorded. Partial Mantel tests were used to assess the relative importance of geographical and environmental distance on community dissimilarity for each grain size (site, cluster, rock). Quantile regressions were used to describe the decay patterns of community similarity with respect to geographical and environmental distances. Ordination analyses and variation partitioning techniques were

This article has been accepted for publication and undergone full peer review but has not been through the copyediting, typesetting, pagination and proofreading process, which may lead to differences between this version and the Version of Record. Please cite this article as doi: $10.1111 /$ jvs. 12790

This article is protected by copyright. All rights reserved. 
applied to assess the pure and shared effects of measured variables on bryophyte community composition.

Results: Environmental distance based upon macro-scale predictors was significantly correlated to community similarity, while no significant correlation was found for ecological distance calculated for micro-scale predictors, except at the largest grain size. The decrease of community similarity with geographical and environmental distance was thus consistently strengthened with increasing sample grain. Compositional variation was best explained by anthropogenic variables.

Conclusions: The relative importance of environmental vs geographical distance on compositional similarity in epilithic bryophyte communities varies with the spatial scale of the predictors and with the sample grain. The decrease of similarity with increasing distance is related to changes in habitat features, especially those driven by human disturbance, while is weakly affected by variations in substrate features.

Keywords: bryophyte communities; compositional turnover; distance decay; environmental gradient; geographical distance; nested design; sample grain; scale-dependence

\section{Introduction}

Bryophytes contribute considerably to plant diversity in several terrestrial ecosystems and represent a fundamental component of habitats that may tip the climatic balance on Earth, e.g. in tundra (Longton, 1992; Rastrorfer, 1978; Russell, 2008), peatlands (Gorham, et al. 1991; Halsey, Vitt \& Gignac, 2000; Longton, 1992) and boreal forests ( Jean, Alexander, Mack \& Johnstone, 2017, Kauserud, Mathiesen \& Ohlson, 2008), where they play a major role in key ecological processes such as $\mathrm{C}$ sequestration and $\mathrm{N}$ fixation (Lindo \& Gonzalez, 2010; Turetsky, 2003). Because of their sensitivity to changes in climatic conditions and air pollutant deposition, bryophytes have been termed "canaries in the coal mine" (Slack, 2011) and used as a key organism group in ecosystem monitoring, e.g., as bioindicators. Thus, given their key ecological role, a thorough understanding of the mechanisms by which bryophyte assemblages interact with the environment is needed.

In particular, identifying patterns of species compositional variation in response to environmental and geographic drivers is crucial for predicting future consequences of landuse and climate changes for this group. Nonetheless, the majority of studies addressing diversity and distributional patterns of bryophyte communities has traditionally focused on alpha diversity, mainly assessed in term of species richness (Gabriel \& Bates, 2005; Hespanhol, Séneca, Figueira \& Sérgio, 2011; Kimmerer \& Driscoll, 2000; Nelson \& Halpern, 2005; Odoret al., 2006; Weibull \& Rydin, 2005).

Patterns of bryophyte compositional turnover (an aspect of beta diversity; see Vellend, 2001) along environmental gradients in the widest sense have received increasing attention over the last decade (Henriques, Borges, Ah-Peng \& Gabriel, 2018; Mateo et al.,2016; Norhazrina et al., 2016; Silva, Dos Santos \& Porto, 2014; Virtanen, Eskelinen, \& Harrison, 2015 ) while minimal attention has been paid so far to the related issue of distance decay of similarity (Nekola \& While, 1999) and to other spatial scale effects on patterns of bryophyte species composition and distribution.

Distance decay is a concept borrowed from geography (Tobler, 1970), addressing the extent to which spatial distance accounts for changes in community similarity. The seminal study by Nekola and White (1999), who investigated patterns of distance decay of both vascular plants and bryophytes in the boreal and mountain spruce-fir forests of North 
America, triggered ecologists' interest in this concept. These authors observed a much lower rate of distance decay in bryophytes than in vascular plants, which they explained by traits of the former such as their vagility and their ability to persist in microsites. This pattern confirmed previous findings by Lee \& La Roi (1979), who first examined species turnover in bryophytes and understory vascular plants. Studying compositional variation along an elevational gradient in the Canadian Rocky Mountains, they observed significantly lower compositional turnover of bryophytes than of vascular plants.

Two main theories are traditionally called upon to account for distance decay of similarity in biological communities: neutral theory (Hubbell 2001), which is based on the assumption that community similarity decays due to species' dispersal limitations, and species-sorting theory which, according to Baas Becking (1934), Nekola \& White (1999) and Leibold et al., (2004), identifies niche-based processes and environmental selection as the main drivers of similarity decrease. The results of several studies (Astorga et al., 2012; Cottenie 2005) suggest that the latter theory explains distance decay patterns in most biological communities, in accordance with the well-known principle that "everything is everywhere, and the environment selects" (Baas Becking 1934). On the other hand, in studies involving different taxonomic groups, the highest rate of distance decay has consistently been observed for the organisms with more limited dispersal abilities (Astorga et al. 2012; Lee and La Roi 1979; Nekola \& White 1999). Dispersal limitations have, however, also been reported for bryophytes, exemplified by some rare liverwort species, which are known to be absent from suitable habitats (Flagmeier, Long, Genney, Hollingsworth \& Woodin, 2013; Jordal \& Hassel 2010; Wangen, Speed \& Hassel 2016, 2017).

To our knowledge, the first specific test of the effects of geographical and environmental distance on species turnover of terrestrial bryophytes was conducted by Silva et al. (2014), who did not find significant effects of deterministic processes on patterns of compositional turnover in epilithic communities of rock outcrops. The question of which of the theories that best explains terrestrial bryophyte composition patterns therefore remains unanswered.

All these studies investigated patterns of compositional turnover along geographical and environmental gradients at one spatial scale or with different extents, as in Silva et al. (2014). However, as pointed out by several authors, the scale-dependence of biodiversity patterns may drive the response to ecological processes (Bacaro et al., 2012; Nekola \& White, 1999; Rahbek, 2005; Soininen, McDonald \& Hillebrand, 2007; Steinbauer, Dolos, Reineking \& Beierkuhnlein, 2012). This opens for the possibility that one and the same group of organisms exhibits different ecological responses to geographic distance and environmental variation at different grain (sampling unit) sizes.

The scale-dependence of distance-decay patterns in biological communities has been highlighted by several studies (Maloney \& Munguia, 2011; Martiny, Eisen, Penn, Allison, \& Horner-Devine, 2011; Nekola \& White, 1999; Soininen et al., 2007; Soininen, Korhonen, Karhu, \& Vetterli, 2011; Steinbauer et al., 2012), of which the majority only focused on the direct relationship between sample grain and observed patterns of distance decay, without exploring the scale-dependence of environmental and geographical controls on such patterns. Hernandez-Hernandez, Borges et al. (2017) recently examined richness and turnover patterns of bryophytes at multiple spatial scales along an altitudinal gradient in the Canary Islands, but neither addressed the effect of grain size on turnover patterns, nor explored the scaledependence of environmental and geographical control on such patterns.

To our knowledge, the present study is the first that explicitly addresses distance decay patterns of terrestrial bryophyte assemblages and that evaluates the relative effect on them of environmental vs geographical distance at multiple spatial scales. 
Bryophytes are recognized as very efficient dispersers (Lönnell, Hylander, Jonsson \& Sundberg, 2012; Medina, Draper \& Lara, 2011; Saur, 1988; Shaw, Szövényi \& Shaw, 2011; Sundberg, 2005, 2013; Szövényi, Sundberg \& Shaw, 2012) and have proved to be able to successfully migrate across oceans. Indeed, Europe and North America currently share about $70 \%$ of their moss flora (Frahm \& Vitt, 1993) and oceanic islands exhibit much lower rates of endemism among bryophytes than among vascular plants (Vanderpoorten, Gradstein, Carine \& Devos, 2010). On the other hand, bryophytes are strictly constrained by micro-climatic conditions, water availability in particular, which is recognized as the main factor limiting their distribution due to its key role for photosynthetic activity and reproduction (Glime, 2017; Hanslin, 1999a; Uchida et al., 2002). Furthermore, unlike vascular plants, bryophytes lack physiological control over water loss (Proctor, 1984; Proctor \& Tuba, 2002), which makes them even more sensible to micro-climatic conditions. The dependence of bryophytes on water has been considered so strict that their abundance is used as a proxy for air humidity (Frahm \& Gradstein, 1991; Karger et al., 2012). The ecological performance of bryophytes is also conditioned by the physical and chemical properties of their substrates, which can significantly mediate their response to climatic drivers (Caruso \& Rudolphi, 2009; Couvreur, San Martin \& Sotiaux, 2016; Halpern, Dovciak, Urgenson \& Evans, 2014; Mills \& Macdonald, 2004; Spitale, 2016). For epilithic and epigeous bryophytes in particular substrate micro-topography is also important (Bayfield, 1976; Hespanhol et al., 2011; Økland R.H., Rydgren \& Økland T., 2008).

Following Astorga et al (2012), we therefore hypothesize that bryophyte species turnover is more affected by variation in niche availability (environmental distance) than by dispersal limitations (geographical distance). We also assume that, although distance decay patterns may vary with grain size, the relative importance of environmental vs geographical control will be almost constant over a range of grain sizes.

The specific aims of this study are: 1) to assess the relative importance of geographical $v s$ environmental distance on patterns of variation in community similarity at different spatial scales; 2) to examine how the composition of epilithic bryophyte communities changes with geographical distance and along ecological gradients at different spatial scales; 3) to test if differences in distance decay patterns exist between mosses and liverworts; and 4) to assess the relative ability of different sets of variables, environmental $v s$ anthropogenic and biotic $v s$ abiotic, to explain variation in species occurrence patterns.

\section{Material and Methods}

Study area

The Serra de Sintra is a subvolcanic massif lying about $25 \mathrm{~km}$ northwest of Lisbon and marking the westernmost edge of the European Continent (Figure 1). It stretches around $10 \mathrm{~km}$ from east to west, and around $5 \mathrm{~km}$ from north to south, reaching $528 \mathrm{~m}$ a.s.l.

The core of this massif is made up of syenites and surrounded by a large ring of granites, which occupies more than half of the eruptive area, and a discontinuous ring of gabbro-diorites. (Kulberg \& Kulberg, 2000). An exceptionally high number of boulders and rocks of intrusive origin, some of them reaching quite remarkable dimensions, occur scattered through the Serra de Sintra, and provide suitable habitats for a considerable number of epilithic species. 
The climate of the Serra de Sintra belongs to the Mediterranean Humid type, with some areas mostly affected by Atlantic microclimatic features and others having typical Mediterranean character. This differentiation depends on the exposure of the slopes (Alcoforado, 1994; Ribeiro, Lautensach \& Daveau, 1987). The close proximity of this massif to the Atlantic Ocean brings about an inrush of winds loaded with water vapour. The consequent formation of the thick fogs which usually wrap the Serra, contributes to very high humidity throughout the year. The mean annual temperature is around $14.6^{\circ} \mathrm{C}$ and the mean annual precipitation amounts to about $800 \mathrm{~mm}$ (Domingos, 2008).

The forest area of this massif covers approximately $50 \mathrm{~km}^{2}, 26 \%$ of which (ca. $13 \mathrm{~km}^{2}$ ) is managed by the State Forest Service (Ribeiro, 1996). During the $18^{\text {th }}$ and $19^{\text {th }}$ centuries the native vegetation, originally consisting of oak woods dominated by Quercus suber, Quercus faginea and Quercus robur, was to a large extent replaced by non-native species used for afforestation of bare areas, such as Pinus pinaster, Eucalyptus globulus and Acacia melanoxylon, which soon grew invasive. Furthermore, in the second half of the 18th century exotic tree species were planted to adorn the many vast estates of the Portuguese royalty and nobility in the Serra. At the time this study was carried out, the species composition and vegetation patterns of the region differed profoundly from the original ones (Pinto da Silva et al., 1991).

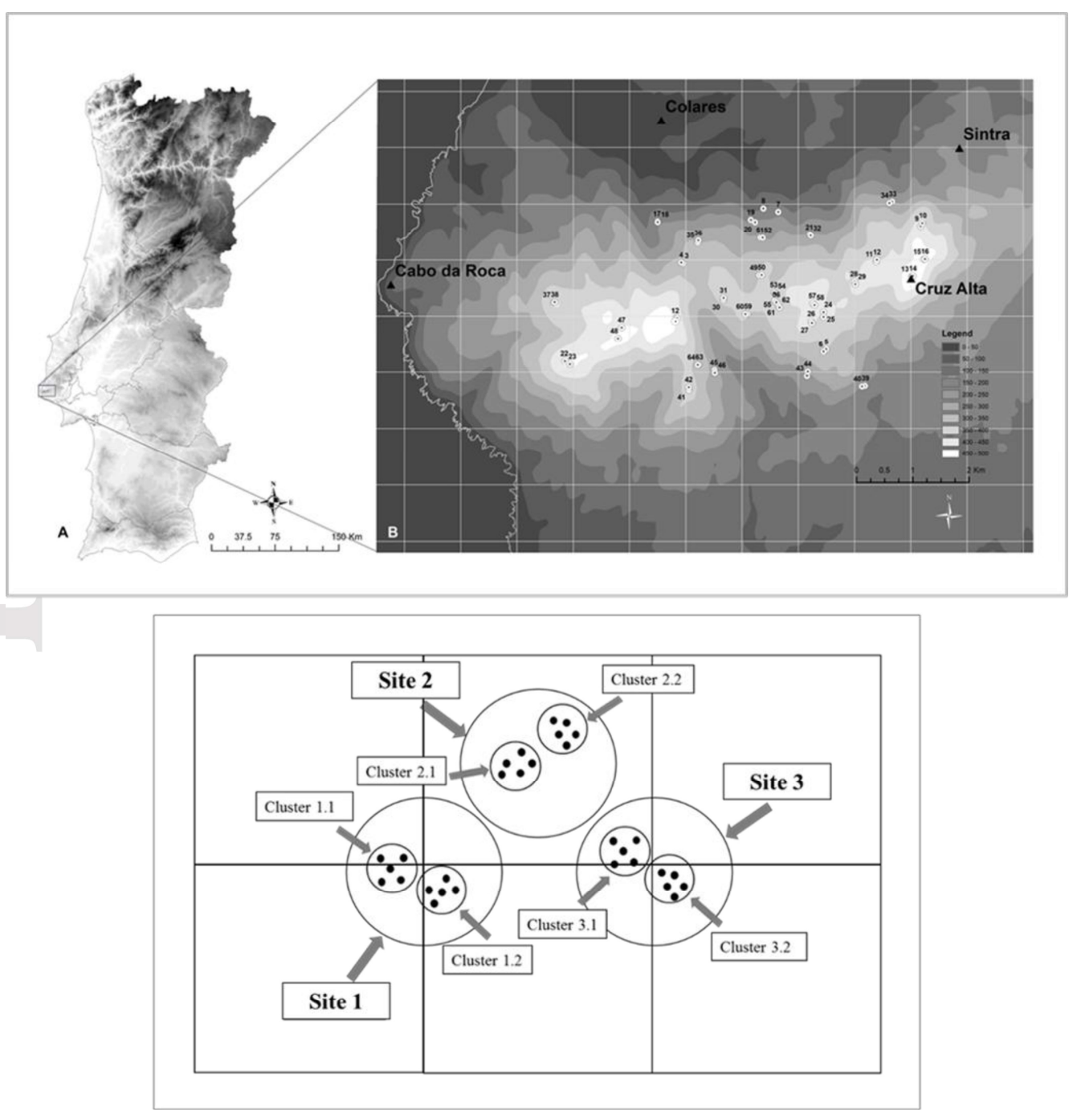

Figure 1. a): Location of the Serra de Sintra within Portugal. b) Map showing the distribution of the selected clusters across the Serra. c) Sketch of the adopted systematic multi-scale sampling scheme. 
The black dots represent individual rocks, grouped in clusters of five, two of which make up a site.

Sampling sites are centered upon each node and central point of the $1 \times 1 \mathrm{~km}$ UTM grid squares.

\section{Sampling design}

Within the study area, which was delimited below by the $200 \mathrm{~m}$ contour, a nested sampling design was adopted to enable analysis of compositional patterns at different spatial scales. A $1 \times 1 \mathrm{~km}$ UTM grid was first superimposed on the study area. Thereafter, the 32 grid-cell centres and nodes (centre points) that neither presented topographic features hindering sampling nor belonged to private properties were selected as centres of circular sampling sites with radius $350 \mathrm{~m}$. At each sampling site, two clusters, each with 5 rocks, were selected (Fig. 1). A cluster was defined as the set of the five closest rocks within $50 \mathrm{~m}$ from the outer perimeter of the five rocks (convex hull calculated in GIS) that, according to visual inspection, satisfied the following criteria: (1) accessibility of substrates - rocks that, for topographic or morphological reasons did not allow access to putative plot positions, were omitted; (2) dimension - no rock smaller than $1.3 \times 1.3 \times 1.3 \mathrm{~m}$ was considered in order to reduce the influence of ground-dwelling species and to have a sufficiently large surface area available for colonization by bryophytes; and (3) presence of at least 3 sides accessible for surveying. Overall, 320 rocks were sampled.

On each selected rock, one $0.5 \times 0.5 \mathrm{~m}$ plot was centered on each rock side facing each of the four cardinal directions (N, S, E, W) and one plot was placed on the top of the rock (T).

All bryophytes occurring in the plots were recorded (see Appendix S1), without discriminating between strict and facultative epiliths. Indeed, the very high humidity levels of the Serra de Sintra throughout the year, provide optimal conditions for bryophytes. Accordingly, epilithic bryophyte communities on rocks are characterized by co-occurrence of species typical of several different substrates. Identification of samples was carried out mainly in the laboratory. The taxonomic nomenclature follows Ros et al. (2007) for liverworts and Ros et al. (2013) for mosses. Fieldwork was carried out between May 2014 and October 2015.

\section{Predictor variables}

Each cluster of rocks was characterized by a set of 15 variables, divided into environmental and anthropogenic (Table 1). These variables, which will hereafter be referred to as macro-scale variables or habitat variables, were selected to represent the factors more likely affecting the distribution of epilithic bryophytes in forest habitats. Most of them were measured in the field, whilesome were acquired from databases available via the web services of the Instituto pela Conservação da Natureza e das Florestas (ICNF) (http://www2.icnf.pt/portal) and of the Sistema Nacional de Informação do Ambiente (SNIAmb) (https://sniamb.apambiente.pt/content/geo-visualizador?language=pt-pt).

Tourism pressure was assigned to each forest parcel or historic park based upon field observations and descriptive information provided by ICNF and Parques de Sintra, Montes da Lua, the institutions administrating the Sintra Natural Park and the historical parks of the area, respectively.

Each rock within each cluster was characterized by 8 variables recorded in the field, which were divided into abiotic and biotic. These variables will be referred to as micro-scale variables, or substrate variables (Table 1). 
Table 1. Macro-scale variables recorded at the cluster scale, divided into environmental and anthropogenic, and micro-scale variables recorded at rock scale, divided into abiotic and biotic. Source $=$ map: data from digital maps or elevation models; source $=$ database: data extracted from other digital sources.

\begin{tabular}{|c|c|c|c|c|c|}
\hline Group & Variable & Description & Source & Type & Min-Max \\
\hline \multirow[t]{9}{*}{ Environmental } & Altitude & Elevation in $\mathrm{m}$ a.s.l. & field & continuous & $200-528$ \\
\hline & Topography & 3 classes: N/S/Plateau & map & nominal & \\
\hline & Tree cover & $\begin{array}{l}4 \text { classes: } 0 \text { to } 100 \% \text { divided into } \\
\text { equal intervals }\end{array}$ & field & ordinal & $1-4$ \\
\hline & Shrub cover & - & field & continuous & $0-100 \%$ \\
\hline & Herb cover & - & field & continuous & $0-100 \%$ \\
\hline & Distance from sea & $\begin{array}{l}\text { 3classes: }(<3 \mathrm{~km}) /(3-9 \mathrm{~km}) / \\
(>9 \mathrm{~km})\end{array}$ & map & ordinal & $1-3$ \\
\hline & Rock type & $\begin{array}{l}3 \text { classes: Granite/ Syenite / } \\
\text { Gabbro }\end{array}$ & map & nominal & \\
\hline & Insolation & Hours peryear & $\begin{array}{l}\text { data } \\
\text { base }\end{array}$ & continuous & $2500-2700$ \\
\hline & Evapotranspiration & Mm per year & $\begin{array}{l}\text { data } \\
\text { base }\end{array}$ & continuous & $500-600$ \\
\hline \multirow[t]{6}{*}{ Anthropogenic } & Tourism pressure & Subjective assignement & & ordinal & $1-5$ \\
\hline & Vegetation type & 2 classes: Semi-natural/Artificial & field & nominal & \\
\hline & Distance from paths & 3 classes: $(<5 \mathrm{~m}) /(5-15) /(>15 \mathrm{~m})$ & field & ordinal & $1-3$ \\
\hline & $\begin{array}{l}\text { Invasive species } \\
\text { cover }\end{array}$ & - & field & continuous & $0-100 \%$ \\
\hline & Alteration of habitat & $\begin{array}{l}2 \text { classes: Presence/ Absence of } \\
\text { extensive logging interventions } \\
\text { during the last } 5 \text { years }\end{array}$ & field & nominal & \\
\hline & Distance from fires & $\begin{array}{l}3 \text { classes related to distance } \\
\text { from areas burnt during the last } \\
50 \text { years: }(150 \mathrm{~m}) /(150- \\
300 \mathrm{~m}) /(>300 \mathrm{~m})\end{array}$ & map & ordinal & $1-3$ \\
\hline \multirow[t]{4}{*}{ Abiotic } & Size of the rock & $>1.30 \times 1.30 \times 1.30 \mathrm{~m}$ & field & ordinal & $1-5$ \\
\hline & Shading & $\begin{array}{l}6 \text { classes: } 0 \text { to } 100 \% \text { divided } \\
\text { into equal intervals. }\end{array}$ & field & ordinal & $1-6$ \\
\hline & Slope & $\begin{array}{l}4 \text { classes: divided into equal } \\
\text { intervals }\end{array}$ & field & ordinal & $1-4$ \\
\hline & Soil coverage & $\begin{array}{l}5 \text { classes: } 0 \text { to } 100 \% \text { divided } \\
\text { into equal intervalssoil }\end{array}$ & field & ordinal & $1-5$ \\
\hline \multirow[t]{4}{*}{ Biotic } & Bryophyte cover & $\begin{array}{l}8 \text { classes: } 0 \text { to } 100 \% \text { divided } \\
\text { into equal intervals. }\end{array}$ & field & ordinal & $1-8$ \\
\hline & Lichen cover & $\begin{array}{l}8 \text { classes: } 0 \text { to } 100 \% \text { divided } \\
\text { into equal intervals. }\end{array}$ & field & ordinal & $1-8$ \\
\hline & Vascular plant cover & $\begin{array}{l}8 \text { classes: } 0 \text { to } 100 \% \text { divided } \\
\text { into equal intervals. }\end{array}$ & field & ordinal & $1-8$ \\
\hline & $\begin{array}{l}\text { Bryophyte cover (all } \\
\text { substrates) within } 3 \mathrm{~m} \\
\text { from each rock }\end{array}$ & $\begin{array}{l}8 \text { classes: } 0 \text { to } 100 \% \text { divided } \\
\text { into equal intervals }\end{array}$ & field & ordinal & $1-8$ \\
\hline
\end{tabular}

\section{Data analysis}

The influence of geographical and environmental distance on species turnover at different grain sizes was evaluated by use of three different metrics: 1) the slope of a quantile regression model; 2) initial similarity and halving distance; and 3) partial Mantel tests. 
The influence of geographical and environmental distances on decay patterns was assessed by analyzing matrices of compositional similarity and dissimilarity among pairs of sampling units, obtained for each spatial scale (rock, cluster or site). We used Jaccard's coefficient of similarity $S_{j}$ (see Podani 2000) calculated as follows:

$S_{j}=\frac{c}{(a+b+c)}$

where $c$ is the number of species shared by two sampling units and $a$ and $b$ are the numbers of unique species occurring in each of the two sampling units. Geographical distances were calculated as Euclidean distances between pairs of sampling units. Environmental distances were calculated separately for micro- and macro-scale variables by a modified version of the Gower distance as implemented in the adiv R package (Pavoine, 2018). This measure can be calculated for a set of environmental variables that comprise different statistical variabletypes (quantitative and ordinal variables; for details see Pavoine, Vallet, Dufour, Gachet, \& Daniel, 2009). Before calculating distance matrices, correlation analysis was performed on quantitative variables in order to assess the degree of multicollinearity (see Appendix S2).

Quantile regressions are statistical methods that seek inference about a $\tau$-th conditional quantile function (Koenker \& Basset, 1978). We obtained the following quantile regressions for $\tau=0.9$ using the $\mathrm{R}$ package quantreg (Koenker, 2018): 1) between the compositional dissimilarity matrix and the micro-scale variable distance matrix, separately for each of the three scales (rock, cluster, site); and 2) between the compositional dissimilarity matrix and the macro-scale distance matrix for the cluster and site scales. $p$ values for a test of the null hyypothesis that there is no relationship are reported for bryophytes overall (Table 4), as well as separately for mosses and liverworts (see Appendix S3)

Initial Similarity (IS) and Halving Distance (HD), calculated according to Soininen et al. (2007), are metrics commonly used in distance decay analyses (e.g., Astorga et al. 2012) to quantify two aspects of species turnover with respect to distance.

IS is defined as the estimated compositional similarity of samples from sites situated a specified, short, distance apart (1 $\mathrm{m}$ in our case); large values of IS thus indicate low turnover at fine spatial scales. HD, which is defined as the distance at which IS is halved, was used to assess the scale-dependency of compositional turnover.

Partial Mantel tests between two matrices conditioned on a third one (Legendre \& Legendre, 2012) were used to assess the effects of geographical and environmental distances on compositional dissimilarity matrices obtained for the three grain sizes (rock, cluster and site) and for the two sets of variables (macro and micro-scale variables). The significance of the partial Mantel test statistic (Spearman's $\rho$ ) was assessed using the Monte Carlo permutation test (999 permutations) in the vegan $\mathrm{R}$ package (Oksanen et al., 2018).

Patterns of species compositional variation in samples and their environmental correlates were further explored using multivariate methods. Specifically, we used the multiple parallel ordination approach (van Son and Halvorsen, 2014) to extract the latent structure of the bryophyte community matrix. Parallel, Non-Metric Multi-dimensional Scaling (NMDS; Kruskal \& Wish, 1978) and Detrended Correspondence Analysis (DCA; Hill \& Gauch, 1980) ordinations were obtained for each of the three spatial scales (see Appendix S4/1). NMDS ordinations were obtained by use of the 'monoMDS' function in the vegan $\mathrm{R}$ package with the following specifications: 100 random starts of the initial configuration, Jaccard distance, maximum number of iterations $=200$; convergence tolerance $=1 \times 10^{-7}$. Then, the solution with the lowest stress value was selected and post-processed in order to linearly rescale axes in half-change units. For each scale, we calculated the correlation coefficient (Kendall' $\tau$ ) between the axes of the parallel ordinations and the 
Procrustes correlation coefficient $r$ (see Appendix S4/2), which expresses the degree of overall similarity between pairs of ordinations. At the cluster scale, we projected the macroscale variables onto the DCA ordination by using the envfit function of the vegan package. Lastly, we produced a DCA ordination diagram with estimated species optima and projected micro-scale variables (Appendix S5)

The variation partitioning approach (Borcard, Legendre \& Drapeau, 1992; Legendre, 2008; Økland, 2003) based on redundancy analysis (RDA, Legendre \& Legendre, 2012) was applied to each group of variables at each spatial scale to assess the proportion of compositional variation explained by their unshared and shared effects. We focused just on the fractions of explained variation by the different sets of explanatory variables following Økland (1999).

To avoid multicollinearity of variables in each group, a forward selection procedure using permutation of residuals under the reduced model and the double-stopping criterion proposed by Blanchet et al. (2008) was applied (based on $\alpha=0.05$; permutations $=999$ ). The adespatial R package (Dray et al., 2018) was used. The effect of space was operationalized using spatial coordinates of the sampling units as predictors. All analyses were performed for all bryophytes and separately for mosses and liverworts, in order to highlight potential differences in the response of the two main taxonomic groups of bryophytes to geographical distance and environmental gradients. All statistical analyses were performed using R 3.5.1 (R Core Team 2018).

\section{Results}

\section{Relative importance of environmental vs geographical distance at the various spatial} scales analysed by partial Mantel tests

The relative importance of geographical distance in shaping community structure (expressed as compositional similarity) for all bryophytes as well as for mosses was highly significant when environmental distance (recorded as micro-scale variables) was controlled for, while the strength of the relationship was weakened when environmental distance based on macro-scale variables was controlled for (Table 2). Conversely, macro-scale environmental distance was significantly correlated with community similarity, whereas no significant correlation was found for micro-scale environmental distance, except at the site scale (Table 2).

Liverworts showed a pattern of compositional similarity decay similar to the pattern found for mosses, except that the variation accounted for by geographical distance was significant only when environmental distance based upon micro-scale variables was controlled for. 
Table 2. Partial Mantel correlations (Sperman's $\rho$ ) between community similarity and environmental distance based on micro- and macro-scale variables, controlling for geographical distance (ED|GD) and vice versa $(\mathrm{GD} \mid \mathrm{ED})$, at different grain sizes. Statistical significance of the comparisons was assessed using partial Mantel tests based on 999 permutations $(* * *=p<0.001 ; * *=p<0.01 ; *=p<$ 0.05). $\mathrm{GD}=$ geographical distance; $\mathrm{ED}=$ environmental distance.

\begin{tabular}{c|c|ll|l|ll}
\hline \multicolumn{2}{|c|}{} & \multicolumn{2}{|c|}{ Micro-scale variables } & \multicolumn{2}{c}{ Macro-scale variables } \\
\hline & Distance & Rock & Cluster & Site & Cluster & Site \\
\hline \multirow{2}{*}{ Bryophytes } & GD $\mid$ ED & $0.21^{* * *}$ & $0.29^{* * *}$ & $0.33^{* * *}$ & $0.11^{*}$ & $0.15^{*}$ \\
\cline { 2 - 7 } & $\mathrm{ED} \mid \mathrm{GD}$ & 0.03 & 0.01 & $0.15^{*}$ & $0.29^{* * *}$ & $0.37^{* * *}$ \\
\hline \multirow{3}{*}{ Mosses } & $\mathrm{GD} \mid \mathrm{ED}$ & $0.19^{* * *}$ & $0.28^{* * *}$ & $0.33^{* * *}$ & $0.12^{*}$ & $0.16^{*}$ \\
\cline { 2 - 7 } & $\mathrm{ED} \mid \mathrm{GD}$ & 0.01 & 0.00 & $0.13^{*}$ & $0.26^{* * *}$ & $0.33^{* * *}$ \\
\hline \multirow{2}{*}{ Liverworts } & $\mathrm{GD} \mid \mathrm{ED}$ & $0.13^{* * *}$ & $0.15^{* *}$ & $0.22^{* *}$ & 0.02 & 0.06 \\
\cline { 2 - 7 } & $\mathrm{ED} \mid \mathrm{GD}$ & 0.03 & 0.00 & $0.12^{*}$ & $0.22^{* * *}$ & $0.32^{* * *}$ \\
\hline
\end{tabular}

Species turnover rates and distance decay patterns at different grain sizes, expressed by the IS and

HD metrics and analysed by quantile regression

The initial similarity (IS) increased consistently with increasing grain (sampling unit) size for bryophytes overall, and for mosses and liverworts analysed separately (Table 3). Halving distance (HD), on the other hand, exhibited the same trend only for bryophytes (Table 3), while negligible differences among grain sizes were found for mosses and an unexpected humped-back pattern was observed for liverworts: species turnover first decreased with increasing grain size and then increased again towards the broadest spatial scales addressed in this study.

Table 3. Initial similarity (IS) and halving distance (HD) expressed in $\mathrm{km}$ for three scales for bryophytes, mosses and liverworts.

\begin{tabular}{|c|l|c|c|c|}
\hline Group & Metric & Rock & Cluster & Site \\
\hline \multirow{2}{*}{ Bryophytes } & IS & 0.36 & 0.48 & 0.56 \\
\cline { 2 - 5 } & HD & 5.97 & 6.05 & 7.01 \\
\hline \multirow{2}{*}{ Mosses } & IS & 0.38 & 0.49 & 0.60 \\
\cline { 2 - 5 } & HD & 6.33 & 6.07 & 6.00 \\
\hline \multirow{2}{*}{ Liverworts } & IS & 0.57 & 0.61 & 0.64 \\
\cline { 2 - 5 } & HD & 5.71 & 10.25 & 8.04 \\
\hline
\end{tabular}

The rate of species turnover (the slope of the quantile regression) for geographic distance and environmental distance, calculated for macro-scale variables, increased (i.e., became more negative) with increasing sample grain, i.e., towards broader spatial scales (Fig. 2 and 3), indicating distance decay of compositional similarity. The same patterns, but less strong, were observed for environmental distances calculated for micro-scale variables (figures not shown). 

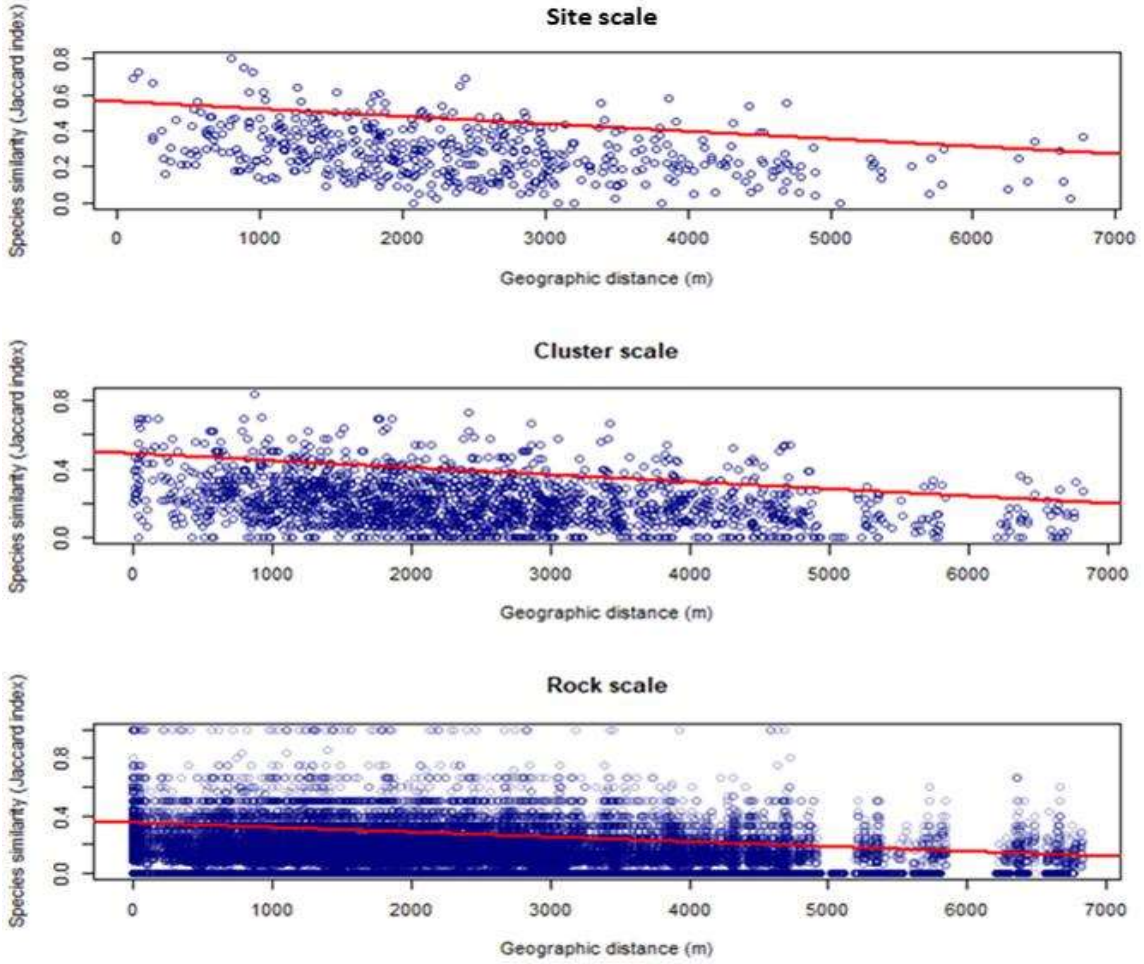

Fig. 2. Decay of community similarity (Jaccard index) of the bryophyte community with increasing distance at different spatial scales. The lines represent the fitted model obtained by quantile regression $(\tau=0.9)$.

Site microscale

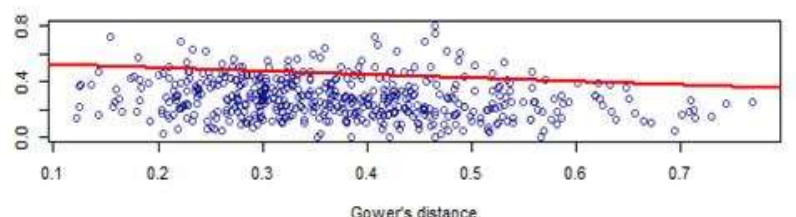

Cluster microscale

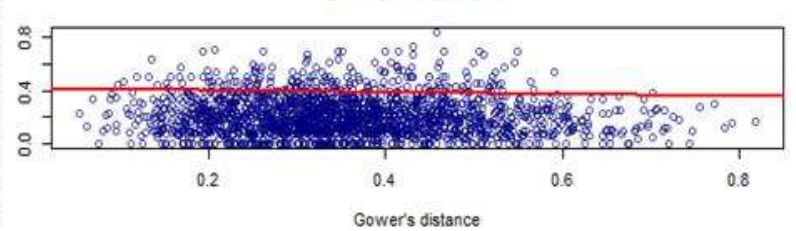

Rock microscale

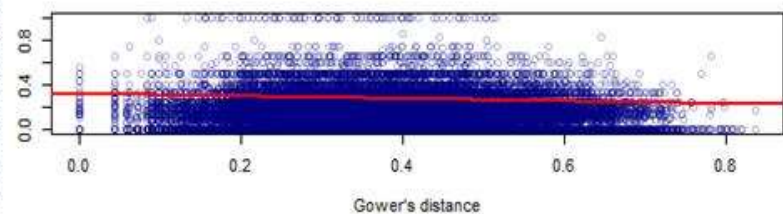

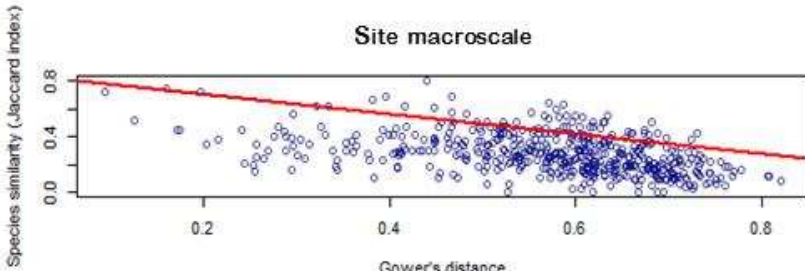

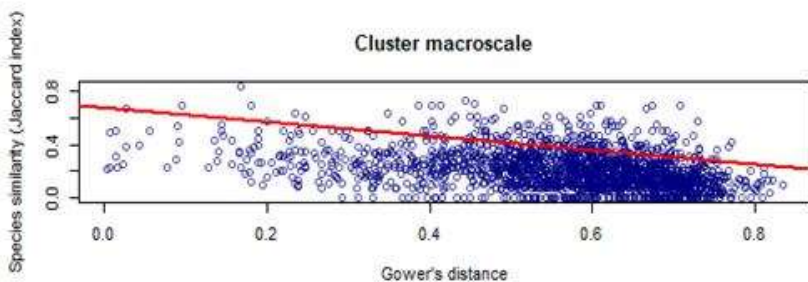

Gower's distance

Fig. 3. Relationship between community similarity and environmental distance for macro- and microscale variables, calculated for three grain sizes. The line represents the fitted model derived from quantile regression $(\tau=0.9)$ 
Table 4: Summary of output from quantile regressions of bryophyte similarity (Jaccard index) as a function of geographic and environmental distances using micro-scale and macro-scale variables) for the three spatial scales addressed in this study.

\begin{tabular}{ccccc}
\hline Distance & Coefficient & Rock & Cluster & Sample \\
\hline \multirow{2}{*}{ Geographic } & Intercept & $0.35845^{* * *}$ & $0.48712^{* * *}$ & $0.56110^{* * *}$ \\
& Slope & $-0.00003^{* * *}$ & $-0.00004 * * *$ & $-0.00004^{* * *}$ \\
\hline \multirow{2}{*}{ Environmental (Micro-scale) } & Intercept & $0.32491^{* * *}$ & $0.41959^{* * *}$ & $0.55071^{* * *}$ \\
& Slope & $-0.11081^{* * *}$ & -0.07075 & $-0.24371^{*}$ \\
\hline \multirow{2}{*}{ Environmental (Macro-scale) } & Intercept & - & $0.68054 * * *$ & $0.85513^{* * *}$ \\
& Slope & - & $-0.53568 * * *$ & $-0.71752^{* * *}$ \\
\hline
\end{tabular}

*** $p<0.001 ; * * p<0.01 ; * p<0.05$

\section{Ordination analysis and variation partitioning}

Multiple parallel ordination analyses showed high concordance (Procrustes correlation coefficient $r=0.80-0.82$ ) between the NMDS and DCA ordinations (Appendix $\mathrm{S} 4 / 2$ ). The first axis of corresponding ordinations for all spatial scales were strongly correlated (Kendall's $\tau \geq 0.80 ; p<0.001$ ), whereas moderate correlations were observed for the second axes (Kendall's $\tau=0.50 ; p<0.001$ for the cluster scale only). Two anthropogenic variables, i.e., vegetation type and tourism pressure, and two environmental variables, i.e., distance from the sea and geological type, were significantly correlated with ordination axes (Fig. 4). The distribution of clusters reproduced the polarization between the two main groups of sampling localities, semi-natural areas characterized by drier conditions (left) and historical parks with higher levels of humidity and stronger habitat diversification (right).

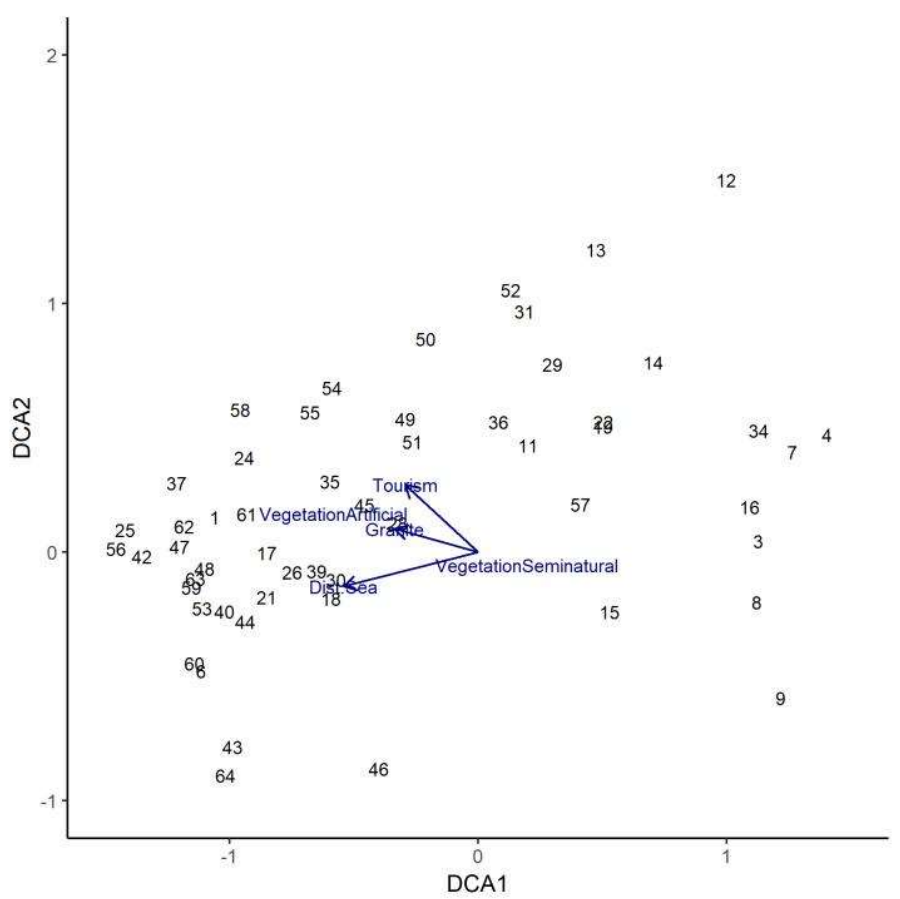

Fig. 4. DCA ordination diagram for the cluster scale with vectors for macro-scale variables fitted by the envfit function of the vegan R package ( 999 permutations). Only variables that are significantly related to the ordination axes $(p<0.05)$ are shown. 
Variation partitioning shows that, for both bryophytes altogether and for mosses, macro-scale variables accounted for a higher proportion of explained variation at the cluster than at the site scale (Table 5) while the proportion of variation in liverwort community composition explained by macro-scale variables differed but little between these two scales. The high proportion of explained variation in liverwort community composition at the site scale explained by macro-scale environmental was entirely due to the unique effect of anthropogenic variables (not shared by environmental variables). Mosses exhibited an opposite pattern, with no variation at the site scale explained by anthropogenic variables. In fact, the relative importance of individual groups of predictors varied strongly among bryophytes, mosses and liverworts (Table 5).

Table 5. Variation components expressed as percentages of the total explained variation. The notation follows Økland (2003) by which A U B means the total variation explained by components $\mathrm{A}$ or $\mathrm{B}, \mathrm{A} \cap \mathrm{B}$ means the variation jointly explained by $\mathrm{A}$ and $\mathrm{B}$, and $\mathrm{A} \mid \mathrm{B}$ mens the variation explianed by A not also by B. Variation components: Envir. = Environmental; Anthro. $=$ Anthropogenic; Bio. $=$ Biotic; Abio. = Abiotic; Spat. $=$ Spatial

\begin{tabular}{|c|c|c|c|}
\hline \multicolumn{4}{|l|}{ Cluster scale } \\
\hline $\begin{array}{l}\text { Macroscale predictors } \\
\text { Envir | (Anthro } U\end{array}$ & Bryophytes & Mosses & Liverworts \\
\hline Spat.) & 31,58 & 27,27 & 20,00 \\
\hline Anthro | (Envir U Spat.) & 26,32 & 31,82 & 25,00 \\
\hline Spat $\mid$ (Envir. U Anthro) & 0,00 & 4,55 & 0,00 \\
\hline (Envir. $\cap$ Anthro) $\mid$ Spat. & 10,53 & 9,09 & 25,00 \\
\hline (Envir. $\cap$ Spat.) $\mid$ Anthro. & 0,00 & 9,09 & 5,00 \\
\hline (Anthro. $\cap$ Spat.) $\mid$ Envir. & 5,26 & 4,55 & 0,00 \\
\hline Anthro. $\cap$ Envir. $\cap$ Spat. & 26,32 & 13,64 & 25,00 \\
\hline \multicolumn{4}{|l|}{ Site scale } \\
\hline $\begin{array}{l}\text { Macroscale predictors } \\
\text { Envir | (Anthro } U\end{array}$ & Bryophytes & Mosses & Liverworts \\
\hline Spat.) & 10,00 & 11,11 & 0,00 \\
\hline Anthro | (Envir U Spat.) & 0,00 & 11,11 & 47,62 \\
\hline Spat $\mid$ (Envir. U Anthro) & 10,00 & 22,22 & 9,52 \\
\hline (Envir. $\cap$ Anthro.) $\mid$ Spat. & 10,00 & 0,00 & 14,29 \\
\hline (Envir. $\cap$ Spat.) $\mid$ Anthro. & 10,00 & 0,00 & 9,52 \\
\hline (Anthro. $\cap$ Spat.) $\mid$ Envir. & 0,00 & 0,00 & 0,00 \\
\hline Anthro. $\cap$ Envir. $\cap$ Spat. & 60,00 & 55,56 & 19,05 \\
\hline \multicolumn{4}{|l|}{ Site scale } \\
\hline Microscale predictors & Bryophytes & Mosses & Liverworts \\
\hline Abio. | (Bio. U Spat.) & 33,33 & 38,46 & 14,29 \\
\hline Bio. | (Abio. U Spat.) & 8,33 & 0,00 & 35,71 \\
\hline Spat. | (Abio. U Bio.) & 41,67 & 46,15 & 28,57 \\
\hline (Abio. $\cap$ Bio. $) \mid$ Spat. & 0,00 & 0,00 & 0,00 \\
\hline (Abio. $\cap$ Spat.) $\mid$ Bio. & 8,33 & 15,38 & 7,14 \\
\hline (Bio. $\cap$ Spat. $) \mid$ Abio. & 8,33 & 0,00 & 14,29 \\
\hline Abio. $\cap$ Bio. $\cap$ Spat. & 0,00 & 0,00 & 0,00 \\
\hline
\end{tabular}


Overall, significant effects of micro-scale predictors on the variation in species composition were found neither at the rock nor at the cluster scale (not shown in Table 5), whereas at the largest grain size, they explained around $42 \%$ of the observed variability for bryophytes, $38 \%$ for mosses and 50\% for liverworts (Table 5). However, while abiotic factors exerted the main control on species compositional variation for mosses and bryophytes overall, biotic variables had the strongest explanatory power for liverworts (Table 5).

\section{Discussion}

\section{Relative importance of environmental vs geographical distance}

Our results suggest that we cannot univocally assess the relative importance of nichebased processes $v s$ spatially limited dispersal on species turnover, unless we specify the scale of investigation, especially in terms of grain size. Specifically, this study highlights that the relative level of control of environmental and geographical distance over patterns of species turnover is strongly dependent on the scale at which environmental variables are selected and, secondarily, on sample grain.

In fact, at both cluster and site scales environmental distance exhibits the strongest control on patterns of species turnover when based on macro-scale variables (although geographical distance still has a significant effect), whereas geographical distance is more important for compositional patterns than micro-scale variables.

The results also show that micro-scale variables become more important relative to geographical distance with increasing grain size (i.e., from rock to site). This indicates that rates of species turnover are controlled by an interaction between scale of drivers and sample grain.

The observed predominance of ecological control over distance decay patterns when macro-scale variables are considered is in line with the results of Astorga et al. (2012) and appears to support the species-sorting theory. On the other hand, the lack of effect of microscale predictors on decrease of similarity among sampling units at the rock and cluster scales suggests that one or both of the following alternative explanations may apply: 1) the selection of micro-scale variables used in this study does not comprise the most important determinants of epilithic bryophyte species composition; and 2) that the distribution of species on fine scales is driven by other processes than environmental selection. Silva et al. (2014) find no significant effect of environmental variation on epilithic bryophyte community similarity, thus concluding that stochastic processes related to distance are the major determinants at both regional and local scales. Moreover, they argue that other factors such as interspecific competition and size of the selected "islands" need to be taken into account to explain local patterns. Indeed, according to Chase \& Meyers (2011) and Hubbell (2001), species distributions in isolated "island" environments are subject to a much higher level of stochasticity than in well-connected environments. In our case, the erratic boulders representing our smallest sampling units can be regarded as delimited "islands amidst a sea of soil" (Silva et al. 2014), which accords with the idea that the composition of their biotic communities is strongly driven by stochastic events.

Our results also imply that macro-scale (or habitat) variables, such as tree cover, vegetation type or management intensity, exert a much stronger effect on species turnover rate of epilithic communities than micro-scale ( substrate or biotic) variables, such as lichen cover, vascular plant cover and size of the rocks. 
The above-described pattern of environmental vs geographical control also holds true when mosses and liverworts are considered separately, which suggests that there is no substantial difference between the two main bryophyte taxa with respect to dispersal abilities and general pattern of response to environmental gradients.

\section{Compositional turnover and distance decay patterns}

The quantile regressions show that the decay of community similarity as a function of larger environmental distances increases with increasing sample grain (from rocks to samples for micro-scale variables, from clusters to samples for macro-scale variables, Table 4), whereas the magnitude of distance decay due to geographical distance is rather constant across scales. The effect of increasing environmental differences on species turnover is thus expected to be stronger for larger grain sizes. This accords with the initial similarity and the halving distances being lowest for bryophytes overall and for liverworts for the smallest sample grain. Indeed, according to neutral theory, the decay of community similarity is expected to be stronger at short spatial distances (Hubbell, 2001; Jones, Tuomisto, Clark \& Olivas, 2006), all the more so for small organisms that promptly respond to fine scale spatial variations in the environment, such as bryophytes (Soininen et al., 2007). The observed patterns confirm the extreme complexity of scale dynamics in biological communities and the necessity to further investigate this issue.

The difference among the trends of halving distance between mosses and liverworts are consistent with the former being overall more stress-tolerant and adaptable than the latter, thus responding less promptly to micro-scale environmental variations. Indeed, liverworts are particularly sensitive to changes in temperature and humidity levels resulting from increased solar radiation, e.g., following forest harvesting (Halpern et al., 2014; Nelson \& Halpern, 2005), because they are strictly dependent on water availability and overall, more sensitive to drought than mosses (Hylander, Dynesius, Jonsson. \& Nilsson, 2005; Kurschner, 1999; Oliver, Velten \& Wood., 2000; Söderström, 1988; ). This could be due to the fact that, unlike mosses, most liverworts have no internal strand of water-conducting cells (Hébant, 1977; Kobiyama \& Crandall-Stotler, 1999), so that micro-site features conditioning the fine-scale availability of water can determine a very swift species turnover. However, what makes mosses overall more desiccation tolerant than liverworts is still mostly unclear and more studies about the eco-physiology of liverworts are needed.

\section{Ordination analysis and variation partitioning}

Ordination analyses identify factors of relevance for supply and retention of air humidity, such as distance from the sea and vegetation type (semi-natural vs artificial), respectively, as particularly important for bryophyte species composition. In fact, while the former indirectly addresses the supplies of water vapour from the ocean to the different sites, the latter, by defining important structural (density and height of canopy cover) and physiological (evapotranspiration levels) environmental constraints, accounts for the permanence of air humidity close to the ground and its availability for bryophytes. Indeed, the luxuriant vegetation of the historical parks of the Serra provides a suitable habitat for the occurrence of a rich bryoflora, consisting of species typical of different bio-geographical regions, among which many hyper-oceanic species with their main distribution in Macaronesia (e.g., Frullania teneriffae, Hypnum uncinulatum, Lejeunea mandonii, Marchesinia mackaii, T. alopecurum var. maderense). In contrast, the more open seminatural woodlands dominated by invasive species such as Eucalyptus gobulus and Acacia 
melanoxylon, exhibit drier environmental conditions and their bryoflora consists almost exclusively of sub-Mediterranean and temperate species (e.g., Campylopus pilifer, Hypnum cupressiforme., Frullania tamarisci).

Our results also indicate that the bedrock type significantly affects bryophyte species composition, which confirms findings of previous studies (Bates, 1978; Cleavitt et al., 2009; Shacklette, 1961; Smith, 1982) and highlights the potential importance of substratum properties in determining diversity of epilithic bryophyte assemblages.

The results of variation partitioning analyses show that, at the cluster scale, environmental variables play a pivotal role in determining overall bryophyte community composition, while anthropogenic variables act as the main drivers for mosses and liverworts. The explanatory power of the selected variables appears to be much weaker at site scale, especially for mosses (and bryophytes overall), while liverworts remain strongly affected by anthropogenic variables at the site scale. The effect of human impact is two-fold. On one hand, management interventions such as forest thinning expose the understory to increased solar radiation, which is expected to decrease bryophyte ecological fitness (Santi et al. 2016). Furthermore, a high share of invasive species contributes to impoverishment of soils and reduction of availability of potential niches for bryophytes. On the other hand, creation of artificial landscapes characterized by abundance of water, dense canopy cover and a variety of micro-habitats may provide a suitable habitat for the establishment and maintenance of a great variety of species by guaranteeing constantly high humidity levels and high substrate diversification.

Spatial distance affects community composition mainly at site scale, while at cluster scale no effect on community composition can be seen, neither for bryophytes overall nor for liverworts, and the effect on mosses is also small. This is probably due to the rather small distances among the selected clusters.

The main differences between bryophytes overall, mosses and liverworts emerge at site scale, and for macro-scale as well as micro-scale variables. Unlike the pattern observed for mosses and bryophytes, environmental variables seemingly affect liverwort community composition just at cluster scale, which suggests that liverworts react to local conditions and take advantage of suitable micro-niches. The strong explanatory power of anthropogenic variables for this group suggests a key role of human impact for organisms that are characterized by narrower ecological niches and are more strictly dependent on suitable conditions provided by artificially built luxuriant habitats. The better balance between environmental and anthropogenic drivers for mosses than for liverworts accords with the assumption that mosses cope better with stress and disturbance. Biotic attributes of the rocks, such as lichen and vascular plant cover, also explain a considerable share of the variation in the composition of liverworts at all the analysed scales, while they are apparently less important for mosses. However, from the results of the DCA ordination with fitted microscale variables (Appendix S5), the distribution of liverworts seem to be more strongly influenced by vascular plant cover than by lichen cover. Specifically, liverworts seem to occur on rocks characterized by low vascular plant cover, which suggest they tend to avoid potentially negative effects due to the presence of vascular plants and to occupy undisturbed and empty niches. As for their relationship with lichens, the segregation of these two groups is consistent with their different physiological adaptations (e.g., with respect to moisture, exposure to wind, substrate roughness) which causes them to occupy separate niches. 


\section{Conclusions}

From the results of this study, we can draw the following conclusions:

1. The relative importance of environmental $v s$ geographical distance on bryophyte species turnover in epilithic communities depends on the spatial scale of predictor selection. In fact, when considering macro-scale environmental predictors distance decay patterns are primarily driven by environmental distance, while if we consider micro-scale predictors geographical distance turns out to be the main driver.

2. Overall, we observe that the variables addressed by us drive distance decay patterns according to a hierarchy of importance: macro-scale $>$ spatial $>$ micro-scale variables. Indeed, the distance decay of similarity in epilithic communities is mainly driven by changes in habitat features, while also affected by variations in substrate features at the largest sample grain size.

3. Despite the similarity of their distance decay patterns, mosses and liverworts differ in their species turnover rates at the various grain sizes and in their responses to both habitat and substrate predictors, with the latter exhibiting a higher sensitiveness to anthropogenic drivers and micro-scale variations.

Our study shows that scale dependency is an important propriety of natural phenomena.

This should therefore be taken into account in studies on species diversity patterns and, in particular, studies on bryophyte communities. In fact, the understanding of the processes underlying species distribution and turnover in bryophyte assemblages is important for selecting the appropriate strategies for conservation of bryophytes and for adapting such strategies to the scale of management.

\section{Acknowledgments}

The realization of this study was made possible thanks to the logistic support and the data provided by Parques de Sintra-Monte da Lua and ICNF. We thus express our warmest thanks to Eng. Nuno Oliveira, Mr. Miguel Fresco and Dr. Conceição Bernardes. We also wish to address special thanks to Rune Halvorsen, for carefully editing our paper and thus considerably contributing to its improvement.

\section{Author contributions}

C.C., A.C. and G.B conceived the ideas; C.C., C.S. and C.G. collected the data; E.T, G.B. and F.P. analysed the data; C.C led the writing; A.C., E.T. G.B. and C.S. critically revised the text.

\section{Data accessibility}

The data used in this study are available from the corresponding author upon request. 


\section{References}

Alcoforado, M. J. (1994) A vegetação como indicador climático. Anais do instituto superior de agronomia 44: 667-681.

Alpert (1986) Distribution quantified by microtopography in an assemblage of saxicolous mosses. Plant Ecology 64: 131-139. https://doi.org/10.1007/BF00044789

Astorga, A., Okansen, J., Luoto, M., Soininen. J., Virtanen, R. \& Muotka T. (2012) Distance decay of similarity in freshwater communities: do macro- and microorganisms follow the same rules? Global Ecology and Biogeography 21: 365-375. https://doi.org/10.1111/j.1466-8238.2011.00681.x

Baas-Becking, L. G. M. (1934), Geobiologie of inleiding tot de milieukunde, The Hague, the Netherlands: W.P. Van Stockum and Zoon.

Bacaro, G., Rocchini, D., Duprè, C., Diekmann, M., Carnesecchi, F., Gori, V. \& Chiarucci, A. (2012). Absence of distance decay in the similarity of plots at small extent in an urban brownfield. Community Ecology 13: 36-44. https://doi.org/10.1556/ComEc.13.2012.1.5

Bates, J. W. (1978) The Influence of Metal Availability on the Bryophyte and Macrolichen Vegetation of Four Rock Types on Skye and Rhum. Journal of Ecology 66: 457-482 https://doi.org/10.2307/2259146

Bayfield, N. G. (1976) Effects of substrate type and micro-topography on establishment of a mixture of bryophytes from vegetative fragments. Bryologist 79: 199-207. https://doi.org/10.2307/3241913

Blanchet, F. G., Legendre, P., \& Borcard, D. (2008). Forward selection of explanatory variables. Ecology, 89: 2623-2632. https://doi.org/10.1890/07-0986.1

Borcard, D., Legendre, P. \& Drapeau, P. (1992) Partialling out the Spatial Component of Ecological Variation. Ecology 73: 1045-1055. https://doi.org/10.2307/1940179

Caruso, A. \& Rudolphi, J. (2009) Influence of Substrate Age and Quality on Species Diversity of Lichens and Bryophytes on Stumps. The Bryologist 112: 520-531. https://doi.org/10.1639/0007-2745-112.3.520

Chase, J. M. \& Meyers, J. A. (2011) Disentangling the importance of ecological niches from stochastic processes across scales. Philosophical transactions of the royal society London, biological science 366: 51-63. https://doi.org/10.1111/j.14610248.2005.00820.x

Cleavitt, N. L., Williams, S.A. \& Slack, N. (2009) Relationship of Bryophyte Occurrence to Rock Type in Upstate New York and Coastal Maine. Northeastern Naturalist 16: 6784 https://doi.org/10.1656/045.016.0106

Cottenie, K. (2005) Integrating environmental and spatial processes in ecological community dynamics. Ecology Letters 8: 1175-1182. https://doi.org/10.1111/j.14610248.2005.00820.x

Couvreur, J. M., San Martin, G., \& Sotiaux, A. (2016) Factors Affecting the Presence and the Diversity of Bryophytes in the Petrifying Sources Habitat (7220) in Wallonia and the Brussels-Capital Region, Belgium. International Journal of Agronomy: 1-18. http://dx.doi.org/10.1155/2016/5365412

Domingos, S. I. S, (2008) Microclimatologia do Município de Sintra com base em estações meteorológicas. Dissertação submetida para a obtenção do grau de Mestre em Ciências Geofísicas - Especialização Meteorologia, Universidade de Lisboa

Dray, S., Bauman, D., Blanchet, G., Borcard, D., Clappe S., Guenard, G., Jombart, T., “...” \& Wagner H. H. (2018). adespatial: Multivariate Multiscale Spatial Analysis. R package version $0.3-2$

Flagmeier, M., Long, D. G., Genney, D. R., Hollingsworth, P. M. \& Woodin, S. J. (2013) 
Regeneration capacity of oceanic-montane liverworts: implications for community distribution and conservation. Journal of Bryology 35: 12-19. https://doi.org/10.1179/1743282012Y.0000000037

Frahm, J. P. \& Gradstein, S. R. (1991) An Altitudinal Zonation of Tropical Rain Forests Using Byrophytes. Journal of Biogeography 18: 669-678. https://doi.org/10.2307/2845548

Frahm, J. \& Vitt, D. H. (1993) Comparisons between the moss floras of North America and Europe. Nova Hedwigia 56: 307-333.

Gabriel, R. \& Bates, J. W. (2005) Bryophyte community composition and habitat specificity in the natural forests of Terceira, Azores. Plant Ecology 177: 125-144. https://doi.org/10.1007/s11258-005-2243-6.

Glime, J. M. (2017) Photosynthesis: Limiting Factors. Chapt. 11-3. In: Glime, J. M. Bryophyte Ecology. Volume 1. Physiological Ecology. Ebook sponsored by Michigan Technological University and the International Association of Bryologists. Available at $<$ http://digitalcommons.mtu.edu/bryophyte-ecology $>$.

Gorham, E. (1991) Northern peatlands: role in the carbon cycle and probable response to climatic warming. Ecological Applications 1:182-195. https://doi.org/10.2307/1941811

Halpern, C.B., Dovciak, M., Urgenson, L. \& Evans, S. A. (2014) Substrates mediate responses of forest bryophytes to a gradient in overstory retention. Canadian Journal of Forest Research 44: 855-866. https://doi.org/10.1139/cjfr-2014-0059

Halsey, L. A., Vitt, D. H. \& Gignac, L. D. (2000) Sphagnum-Dominated Peatlands in North America since the Last Glacial Maximum: Their Occurrence and Extent. The Bryologist 103: 334-352

Hanslin, H. M. (1999a) Seasonal dynamics of biomass increase and shoot elongation in five co-occurring boreal forest bryophytes. Journal of Bryology 21: 5-15. https://doi.org/10.1179/jbr.1999.21.1.5

Harmens, H., Foan, L., Simon V., \& Mills, G. (2011). Mosses as biomonitors of atmospheric POPs pollution: A review. Report for Defra contract AQ08610, available at http://icpvegetation.ceh.ac.uk and http://uk-air.defra.gov.uk/library/.

Hébant, C. (1973) Diversity of structure of the water-conducting elements in liverworts and mosses. Journal of Hattori Botanical Laboratory 37: 229-234.

Henriques, D., Borges, P. A. V., Ah-Peng, C. \& Gabriel, R. (2016) Mosses and liverworts show contrasting elevational distribution patterns in an oceanic island (Terceira, Azores): the influence of climate and space. Journal of Bryology 38: 183-194. https://doi.org/10.1080/03736687.2016.1156360

Hernandez-Hernandez, R., Borges, P. A. V., Gabriel, R., Rigal, F., Ah-Peng, C. \& GonzalezMancebo, J. M. (2017) Scaling a- and b-diversity: bryophytes along an elevational gradient on a subtropical oceanic Island (La Palma, Canary Islands). Journal of Vegetation Sciences 28: 1209-1219. https://doi.org/10.1111/jvs.12573

Hespanhol, H., Séneca, A., Figueira, R. \& Sérgio C. (2011) Microhabitat effects on bryophyte species richness and community distribution on exposed rock outcrops in Portugal. Plant Ecology \& Diversity 4: 251-264. https://doi.org/10.1080/17550874.2011.616546

Hill M. O. \& Gauch H. G. (1980). Detrended correspondence analysis: an improved ordination technique. Vegetatio 42, 47-58. https://doi.org/10.1007/BF00048870

Hubbell, S. P. (2001) The unified neutral theory of biodiversity and biogeography. Princeton University Press, Princeton, NJ.

Hylander, K., Dynesius, M, Jonsson, B. G. \& Nilsson, C. (2005) Substrate form determines the fate of bryophytes in riparian buffer strips. Ecological Applications 15: 674-688. 
https://doi.org/10.1007/BF00048870

ICNF (http://www2.icnf.pt/portal)

Jean, M., Alexander, H. D., Mack, M. C. \& Johnstone, J. F. (2017) Patterns of bryophyte succession in a 160-year chronosequence in deciduous and coniferous forests of boreal Alaska. Canadian Journal of Forest Research 47: 1021-1032. https://doi.org/10.1139/cjfr-2017-0013.

Jones, M. M., Tuomisto H., Clark D. B. \& Olivas, P. (2006) Effects of mesoscale environmental heterogeneity and dispersal limitation on floristic variation in rain forest ferns. Journal of Ecology 94, 181-195. https://doi.org/10.1111/j.13652745.2005.01071.x

Jordal, J. B. \& Hassel, K. (2010) The rare liverwort Scapania nimbosa - new knowledge about distribution and ecology in Norway. Lindbergia 33: 81-91.

Karger, D. N., Kluge, J., Stefan, A., Salazar L., Homeier, J., Lehnert, M. \& Kessler, M. (2012) Bryophyte cover of trees as proxy for air humidity in the tropics. Ecological Indicators 20: 277-281 https://doi.org/10.1016/j.ecolind.2012.02.026.

Kauserud, H., Mathiesen, C. \& Ohlson, M. (2008) High diversity of fungi associated with living parts of boreal forest bryophytes. Botany 86: 1326-1333 https://doi.org/10.1139/B08-102.

Kimmerer R. W. and Driscoll M. J. L. (2000) Bryophyte Species Richness on Insular Boulder Habitats: The Effect of Area, Isolation, and Microsite Diversity. The Bryologist 103: 748-756

Kobiyama,Y. \& Crandall-Stotler, B. (1999) Studies of specialized pitted parenchyma cells of the liverwort Conocephalum Hill and their phylogenetic implications. International Journal of Plant Science 160: 351-370. https://doi.org/10.1086/314126

Koenker, R \& Basset G. (1978) Regression quantiles. Econometrica 46(1): 33-50. https://doi.org/10.2307/1913643.

Koenker, R. (2018). quantreg: Quantile Regression. R package version 5.36. https://CRAN.R-project.org/package=quantreg.

Kulberg, M. C. \& Kulberg J. C. (2000) Tectónica da região de Sintra. In: Tectónica das regiões de Sintra e Arrábida. Mem. Geociências 2 (pp.1-34). Museu Nacional Historia Natural, Universidade de Lisboa.

Kurschner H. (1999) Life strategies of epiphytic bryophytes in Mediterranean Pinus woodlands and Platanus orientalis alluvial forests of Turkey. Cryptogamie Bryologie 20: 17-33. https://doi.org/10.1016/S1290-0796(99)80004-2

Kruskal J. B. \& Wish M. (1978) Multidimensional scaling, Sage University paper series on quantitative application in the social Sciences, 07-011. Sage Publications, Beverly Hills and London

Lee, T. D. \& La Roi, G. H. (1979) Bryophyte and Understory Vascular Plant Beta Diversity in Relation to Moisture and Elevation Gradients. Plant Ecology 40: 2938. https://doi.org/10.1007/BF00052012

Legendre, P. (2008) Studying beta diversity: ecological variation partitioning by multiple regression and canonical analysis. Journal of Plant Ecology 1: 3-8. https://doi.org/10.1093/jpe/rtm001

Legendre, P. \& Legendre, L. (2012) Numerical Ecology. 3rd English Edition. Elsevier.

Leibold, M. A., Holyoak, M., Mouquet, N., Amarasekare, P., Chase, J. M., Hoopes, M. F., Holt, R. D. “...” \& Gonzalez A. (2004). The metacommunity concept: a framework for multi-scale community ecology. Ecology Letters 7: 601-613. https://doi.org/10.1111/j.1461-0248.2004.00608.x

Lindo, Z. \& Gonzalez, A. (2010) The bryosphere: an integral and influential component of the Earth's biosphere. Ecosystems 13: 612-627. https://doi.org/10.1007/s10021-010- 
9336-3

Lönnell, N., Hylander, K., Jonsson, B. G. \& Sundberg, S. (2012) The fate of the missing spores - patterns of realized dispersal beyond the closest vicinity of a sporulating moss. Plos One 7, e41987. https://doi.org/10.1371/journal.pone.0041987

Maloney, K. O. \& Munguia, P. (2011) Distance decay of similarity in temperate aquatic communities: effects of environmental transition zones, distance measure, and life histories. Ecography 34: 287-295. https://doi.org/10.1111/j.1600-0587.2010.06518.x

Martiny, J. B. H, Eisen, J. A., Penn, K., Allison, S.D. \& Horner-Devine, M. C. (2011) Drivers of bacterial $\beta$-diversity depend on spatial scale. Proceedings of National Academy of Sciences 108: 7850-7854. https://doi.org/10.1073/pnas.1016308108.

Mateo, R. G., Broennimann, O., Normand, S., Petitpierre, B., Araújo, M. B., Svenning, J. C., Baselga A. \& Vanderpoorten, A. (2016) The mossy north: an inverse latitudinal diversity gradient in European bryophytes. Scientific Reports 6, 25546. https://doi.org/10.1038/srep25546

Medina, N. G., Draper, I. \& Lara, F. (2011) Biogeography of mosses and allies: Does size matter? Biogeography of microscopic organisms. Is everything small everywhere? Cambridge University Press. https://doi.org/10.1017/CBO9780511974878.012

Mills, S. E. \& Macdonald S. E. (2004) Predictors of Moss and Liverwort Species Diversity of Microsites in Conifer-Dominated Boreal Forest." Journal of Vegetation Science 15: 189-198. https://doi.org/10.1111/j.1654-1103.2004.tb02254.x

Nekola, J. C. \& White, P. S. (1999) The distance decay of similarity in biogeography and ecology. Journal of Biogeography 26: 867-878. https://doi.org/10.1046/j.13652699.1999.00305.x

Nelson, C. R. \& Halpern, C. B. (2005) Short-term effects of timber harvest and forest edges on ground-layer mosses and liverworts. Canadian Journal of Botany 83: 610-620. https://doi.org/ 10.1139/b05-036.

Odor, P., Heilmann-Clausen, J., Christensen, M., Aude, E., van Dort, K. W., Piltaver, A., Siller I. “..." \& Grebnec T. (2006) Diversity of dead wood inhabiting fungi and bryophytes in semi-natural beech forests in Europe. Biological Conservation 131: 5871. https://doi.org/10.1016/j.biocon.2006.02.004

Økland, R. H. (1999) On the variation explained by ordination and constrained ordination axes. Journal of Vegetation Science 10: 131-136. https://doi.org/10.2307/3237168.

Økland, R.H. (2003). Partitioning the variation in a plotby-species data matrix that is related to $\mathrm{n}$ sets of explanatory variables. Journal of Vegetation Science 14: 693-700. https://doi.org/10.1111/j.1654-1103.2003.tb02201.x

Økland R.H., Rydgren, K. \& Økland T. (2008). Species richness in boreal swamp forests of SE Norway: the role of surface microtopography. Journal of Vegetation Science 19: 67-74. https://doi.org/10.3170/2007-8-18330

Oliver, M. J., Velten, J. \& Wood, A. J. (2000) Bryophytes as experimental models for the study of environmental stress tolerance: Tortula ruralis and desiccation-tolerance in mosses. Plant Ecology 151: 73-84 https://doi.org/10.1023/A:1026598724487

Oksanen, J., Guillame Blanchet, F., Friendly, M., Kindt, R., Legedre, P., McGlinn, D., Minchin, P. R. “...” \& Wagner, H. (2018) vegan: Community Ecology Package. Ordination methods, diversity analysis and other functions for community and vegetation ecologists. Version 2.5-1. https://CRAN.R-project.org/package=vegan

Pavoine, S., Vallet, J., Dufour, A. B., Gachet, S. \& Daniel, H. (2009) On the challenge of treating various types of variables: application for improving the measurement of functional diversity. Oikos 118: 391-402. https://doi.org/10.1111/j.16000706.2008.16668.x.

Pavoine S. (2018). adiv: Analysis of Diversity. R package version 1.2. 
Pinto da Silva, A. R., De Bacelar, J. J. A. H., Catarino, M., Correi, A. I. D., Escudeiro, A. S. C., Leitão Serra, M. D. G. \& Rodrigues, C. M. A. (1991) A Flora da Serra de Sintra. Portugaliae acta biologica (B) 15, 5-258.

Podani, J. (2000) Introduction to the exploration of multivariate biological data. 2000. Backhuys, Leiden, NL.

Proctor, M. C. F. (1984) Structure and ecological adaptation. In: Dyer, A. F. and Duckett, J. G. (eds.). The Experimental Biology of Bryophytes (pp. 9-37). Academic Press, London,.

Proctor, M. C. F. \& Tuba, Z. (2002) Poikilohydry and homoihydry: antithesis or spectrum of possibilities? New Phytologist 156: 327-349. https://doi.org/10.1046/j.14698137.2002.00526.x

Rahbek, C. (2004) The role of spatial scale and the perception of large-scale species-richness patterns. Ecology Letters 8: 224-239. https://doi.org/10.1111/j.14610248.2004.00701.x

Rastrorfer, J. R. (1978) Composition and bryomass of the mosso layer of two wet-tundra meadow communities near Barrow, Alaksa. In: Tieszen L. L.: Vegetation and Production Ecology of an Alaskan Arctic Tundra, 169-183. New York, SpringerVerlag.

Ribeiro, O., Lautensach, H. \& Daveau, S. (1987) Geografia de Portugal. O ritmo climático e a paisagem Vol. III. Lisboa, Edições João Sá da Costa.

Ribeiro, J. C. (1996) Sintra: património da humanidade. Sintra, Câmara Municipal de Sintra

Ros, R. M., Mazimpaka, V., Abou-Salama, U., Aleffi, M., Blockeel, T.L., Brugués, M., Cano M. J.,"..." \& Söderström, L. (2007) Hepatics and Anthocerotes of the Mediterranean, an annotated checklist. Cryptogamie, Bryologie 28: 351-437.

Ros, R. M., Mazimpaka, V., Abou-Salama, U., Aleffi, M., Blockeel, T. L., Brugués, M., Cros R. M “...” \& Werner, O. (2013) Mosses of the Mediterranean, an annotated checklist. Cryptogamie Bryologie 34: 99-283. https://doi.org/10.7872/cryb.v34.iss2.2013.99

Russell, S. (2008) Bryophyte production and decomposition in tundra ecosystems. Botanical Journal of the Linnean Society 104, 3-22. https://doi.org/10.1111/j.10958339.1990.tb02208.x

Santi, E., Bacaro, G., Rocchini, D., Chiarucci, A., Bonini, I., Brunialti, G., Muggia, L., Maccherini, S. (2016) Methodological issues in exploring cross-taxon congruence across vascular plants, bryophytes and lichens. Folia Geobotanica 51, 297-304. https://doi.org/10.1007/s12224-016-9265-9

Saur, J. D. (1988) Plant migration. University of California Press, Berkeley, California, USA. Shacklette, H. T. (1961) Substrate Relationships of Some Bryophyte Communities on Latouche Island, Alaska. The Bryologist 64: 1-16. https://doi.org/10.2307/3240917

Shaw, J., , Szövényi, P. \& Shaw B. (2011) Bryophyte diversity and evolution: Windows into the early evolution of land plants. American Journal of Botany 98: 352-369. https://doi.org/10.3732/ajb.1000316.

Silva, J. B., Dos Santos, N. D. \& Porto K. C. (2014) Beta-diversity: Effect of Geographical Distance and Environmental Gradients on the Rocky Outcrop Bryophytes. Cryptogamie, Bryologie 35:133-163. https://doi.org/10.7872/cryb.v35.iss2.2014.133

Sistema Nacional de Informaçao do Ambiente (https://sniamb.apambiente.pt/content/geovisualizador?language $=\mathrm{pt}-\mathrm{pt}$ ). Last access: January 2019.

Slack, N. G. (2011) Ecological value of bryophytes as indicators of climatic changes. In Tuba, Z., Slack, N. G., \& Stark, L. R. (2011) Bryophyte Ecology and Climate Change, Cambridge University Press.

Smith, A. J. E. (1982) Epiphytes and Epiliths. In: Smith A.J.E. (eds) Bryophyte Ecology. Springer, Dordrecht. https://doi.org/10.1007/978-94-009-5891-3_7 
Soderstrom, L. (1988) The occurrence of epixylic bryophyte and lichen species in an old natural and a managed forest stand in Northeast Sweden. Biological Conservation 45:169-178 https://doi.org/10.1016/0006-3207(88)90137-1.

Soininen, J., , H. (2007) The distance decay of similarity in ecological communities. Ecography 30: 3-12. https://doi.org/10.1111/j.0906-7590.2007.04817.x

Soininen, J., Korhonen, J. J., Karhu, J. \& Vetterli, A. (2011) Disentangling the spatial patterns in community composition of prokaryotic and eukaryotic lake plankton. Limnology and Oceanography 56:508-520. https://doi.org/10.4319/1o.2011.56.2.0508

Spitale, D. (2016) The interaction between elevational gradient and substratum reveals how bryophytes respond to the climate. Journal of Vegetation Science 27: 844-853. https://doi.org/10.1111/jvs.12403

Steinbauer, M. J., Dolos, K., Reineking, B. \& Beierkuhnlein, C. (2012) Current measures for distance decay in similarity of species composition are influenced by study extent and grain size. Global Ecology and Biogeogry 21: 1203-1212. https://doi.org/10.1111/j.1466-8238.2012.00772.x

Sundberg, S. (2005) Larger capsules enhance short-range spore dispersal in Sphagnum, but what happens further away? Oikos 108: 115-124. https://doi.org/10.1111/j.00301299.2005.12916.x

Sundberg, S. (2013) Spore rain in relation to regional sources and beyond. Ecography 36: 364 -373. https://doi.org/10.1111/j.1600-0587.2012.07664.x

Szövényi, P., Sundberg, S. \& Shaw, A.J. (2012) Long-distance dispersal and genetic structure of natural populations: An assessment of the inverse isolation hypothesis in peat mosses. Molecular Ecology 21: 5461-5472.

Tilman, D. (1982) Resource competition and community structure. Princeton University Press, Princeton, NJ.

Tobler, W. R. (1970) A computer movie simulating urban growth in the Detroit region. Economic Geography 46: 234-240.

Turetsky, M. R. (2003) The role of bryophytes in carbon and nitrogen cycling. The Bryologist 106: 395 - 409. https://doi.org/10.1639/05

Uchida, M., Muraoka, H., Nakatsubo, T., Bekku, Y., Ueno, T., Kanda, H. \& Koizumi, H. (2002) Net Photosynthesis, Respiration, and Productionm of the Moss Sanionia uncinata on a Glacier Foreland in the High Arctic, Ny-Ålesund, Svalbard. Arctic, Antarctic, and Alpine Research 34: 287-292. https://doi.org/10.1080/15230430.2002.12003496.

Vanderpoorten, A., Gradstein, S. R., Carine, M. A. \& Devos, N. (2010) The ghosts of Gondwana and Laurasia in modern liverwort distributions. Biological Reviews of the Cambridge Philosophical Society 85: 471-487. https://doi.org/10.1111/j.1469185X.2009.00111.x

Vellend, M. 2001. Do commonly used indices of $\beta$-diversity measure species turnover? Journal of Vegetation Science 12: 545-552. https://doi.org/10.2307/3237006

Virtanen, R., Eskelinen, A. \& Harrison, S. (2015) Bryophyte diversity in Californian grasslands in relation to substrate quality, exotic vascular plants and disturbance. Biodiversity and Conservation 24, 103-116 https://doi.org/10.1007/s10531-014-07934.

Wangen, K., Speed, J. D. M. \& Hassel, K. (2016) Hyper-oceanic liverwort species of conservation concern: evidence for dispersal limitation and identification of suitable uncolonised regions. Biodiversity and Conservation 25: 1053-1071 https://doi.org/10.1007/s10531-016-1105-y. 
Wangen, K., Speed, J. D. M. \& Hassel, K. (2017) How does microclimate affect the growth of the rare liverwort Scapania nimbosa? Lindbergia 40: 1-10. https://doi.org/10.25227/linbg.01072

Weibull, H. \& Rydin, H. (2005) Bryophyte species richness on boulders: relationship to area, habitat diversity and canopy tree species. Biological Conservation 122, 1: 71-79. https://doi.org/10.1016/j.biocon.2004.07.001

\section{Supporting information}

Appendix S1: Bryophyte taxa occurring in the survey.

Appendix S2: Correlation matrix (Spearman' $\rho$ ) of the quantitative variables considered in this study on cluster and site scale.

Appendix S3: Summary output of quantile regressions computed on mosses and liverworts similarity (Jaccard's index) as a function of geographic and environmental distances (both using micro-scale and macro-scale variables) for the three spatial scale available

Appendix S4: 1) Multiple parallel ordination results (DCA and NMDS) at a) at rock scale; b) cluster scale; c) site scale. 2) Comparison of DCA and NMDS results at each spatial scale. 